p-ISSN 0044-1600

e-ISSN 2392-3458

\section{Zagadnienia Ekonomiki Rolnej \\ Problems of Agricultural Economics \\ 2(355) 2018, 28-40}

DOI: $10.30858 /$ zer/92060

\title{
STRAW AS ALTERNATIVE ENERGY SOURCE OR ORGANIC MATTER IN THE SOIL
}

\author{
MAREK ZIELIŃSKI \\ WOJCIECH ZIĘTARA
}

\begin{abstract}
The paper aims, above all, at assessment of the effects of allocating straw surplus from the Polish agriculture to energy purposes or as a source of additional organic matter in the soil. Consequently, the authors discuss the issue of significance of straw as an alternative energy source and draw attention to the role of organic matter in improving the production potential of soils and carbon dioxide $\left(\mathrm{CO}_{2}\right)$ sequestration. Additionally, the paper analyses economic effects and development possibilities of farms having non-negative balance of $\mathrm{CO}_{2}$ sequestration at the backdrop other farms. The study used literature data from 2,069 farms specialising in cereal, oilseed crop and high protein crop farming and running accountancy for the Polish FADN in 2015.
\end{abstract}

Keywords: straw, energy, organic matter, $\mathrm{CO}_{2}$ sequestration, farm, alternative.

JEL codes: Q42, Q52, Q56.

Prof. dr hab. Wojciech Ziętara, Instytut Ekonomiki Rolnictwa i Gospodarki Żywnościowej - Państwowy Instytut Badawczy, Zakład Ekonomiki Gospodarstw Rolnych; ul. Świętokrzyska 20, 00-002 Warszawa (wojciech.zietara@ierigz.waw.pl).

Dr inż. Marek Zieliński, Instytut Ekonomiki Rolnictwa i Gospodarki Żywnościowej - Państwowy Instytut Badawczy, Zakład Ekonomiki Gospodarstw Rolnych; ul. Świętokrzyska 20, 00-002 Warszawa (marek.zielinski@ierigz.waw.pl). 


\section{Introduction}

The views of academics and decision-makers as well as the broad public opinion, are highly convergent as regards the impact of increased greenhouse gas emissions $^{1}$ on climate change manifesting itself in climate warming and the aggravation of adverse phenomena, such as periodic droughts, violent storms and hurricanes. The main source of greenhouse gas emissions is the combustion of fossil energy carriers: hard coal and lignite, crude oil and diesel oils and gasoline made of it. The rapid development of the industry initiated in the mid-nineteenth century, the development of motorisation, as well as of cities (heating of flats, air conditioning, etc.) resulted in the increased demand for and consumption of energy. At the same time, awareness of the scarcity of fossil energy sources is growing. The development of nuclear energy due because of disasters, causes social resistance and renders this source of energy less attractive.

This resulted in starting a search for alternative and environmentally friendly sources of energy such as wind, hydro, solar, geothermal energy, ethanol and vegetable oils, biogas and biomass ${ }^{2}$ combustion. One of the components of biomass is straw from cereals, maize, rapeseed and legumes. It can be a source of thermal energy (combustion in special furnaces) or electric energy (combustion in power plants). In the opinion of many authors, straw can be treated as a source of energy, which during the combustion process does not increase greenhouse gas emissions (carbon dioxide $^{3}$ ). In this situation, it is essential to ask about the use of straw for energy purposes where, according to the widely used European classification, about $90 \%$ of Polish soils are characterised by a very low $(<1 \%)$ and low $(1-2 \%)$ share of organic matter (Kuś and Kopiński, 2012). In addition, the currently widespread trends in Polish agriculture, i.e. simplification of production, high share of cereals in the sowing area, low share of legumes and grasses in field crops, declining stocking density and popularisation of litter-free forms of animal rearing contribute to a fall in organic fertilising and thus to a reduction in the share of organic matter in the soil. Importantly, according to Kuś and Kopiński, the average balance of organic matter in Polish agricultural soils (without ploughing in of straw) in 2000 and 2009 was negative and amounted, respectively, to: -0.16 and -0.14 t/ha (Kuś and Kopiński, 2012).

\section{Objective, material and method of studies}

The primary objective of the study is an attempt at assessment of the effects of allocating the surplus of straw in Polish agriculture for energy purposes or as a source of additional soil organic matter, and assessment of its role in improving the production potential of soils and in $\mathrm{CO}_{2}$ sequestration. In addition, the objective

\footnotetext{
${ }^{1}$ Greenhouse gases - gaseous components of the Earth's atmosphere causing the greenhouse effect, i.e. increased temperature of the Earth's surface. They include: steam $\left(\mathrm{H}_{2} \mathrm{O}\right)$, carbon dioxide $\left(\mathrm{CO}_{2}\right)$, methane $\left(\mathrm{CH}_{4}\right)$, nitrous oxide $\left(\mathrm{N}_{2} \mathrm{O}\right)$, sulphur dioxide $\left(\mathrm{SO}_{2}\right)$, ozone $\left(\mathrm{O}_{3}\right)$, hydrofluorocarbons $(\mathrm{HFC})$, perfluorocarbon (PFC) and sulphur hexafluoride (SF6).

${ }^{2}$ Biomass - solid or liquid substances of plant or animal origin, which are biodegradable.

${ }^{3}$ The burning of straw results in the zero balance of $\mathrm{CO}_{2}$ emissions. When straw is being burnt, $\mathrm{CO}_{2}$ emissions are equal to $\mathrm{CO}_{2}$ accumulation in the plant vegetation period (Jarosz, 2016).
} 
of the paper is to assess the economic situation and development opportunities of farms with the non-negative $\mathrm{CO}_{2}$ sequestration balance.

The literature data was used to achieve the basic objective of the studies. On the other hand, to assess the economic situation and development opportunities of farms with the non-negative $\mathrm{CO}_{2}$ sequestration balance, the data has been used from 2069 farms specialising in the cultivation of cereals, oilseeds and protein crops and keeping accounting for the Polish FADN in 2015. To provide the necessary figures for this analysis, at the first stage the farms were divided into two groups. The first group included 1702 farms with the non-negative $\mathrm{CO}_{2}$ sequestration balance. The other group contained 367 remaining farms. Then, at the second stage the group of the farms with the non-negative $\mathrm{CO}_{2}$ sequestration balance was divided into two subgroups. The first subgroup included 851 farms with sequestration balance above the median of the non-negative $\mathrm{CO}_{2}$ sequestration balance, hereinafter referred to as the farms with the non-negative balance I, while the other included the remaining 851 farms with sequestration balance equal or lower than the median of the non-negative $\mathrm{CO}_{2}$ sequestration balance (farms with the non-negative balance II). Finally, comparative analysis covered the farms with the non-negative $\mathrm{CO}_{2}$ sequestration balance I and II and the remaining farms. The $\mathrm{CO}_{2}$ sequestration balance was calculated using the coefficients of reproduction and degradation of organic matter as a result of plant cultivation. In addition, those coefficients took into account the weight of animal manure produced or purchased ${ }^{4}$, as well as the weight of ploughed in straw, other post-harvest residues and green fertilisers ${ }^{5}$ (Fotyma and Mercik, 1995; Harasim, 2006). Analysis also included the weight of straw sold from the farm. Then, knowing that 1 tonne of organic matter contains, on average, $580 \mathrm{~kg}$ of organic carbon, its amount was converted into the amount of $\mathrm{CO}_{2}$, by multiplying each time the amount of organic carbon by 3.67 . This coefficient is due to the fact that the molecular weight of $\mathrm{CO}_{2}$ is 44 units6, and the weight of organic carbon is 12 units (Harasim, 2006).

\section{Straw as an alternative source of energy}

The estimates carried out indicate that in Poland the annual production of straw in 2010-2014 ranged from 28.9 million tonnes in 2011 to 35.6 million tonnes in 2014. According to the forecast, in 2020 and 2030, the production of straw should be about 30.5 million tonnes (Madej, 2016; Jarosz, 2016). The surplus of straw after satisfying the needs of agriculture (feed, litter, substrate for mycelium and for ploughing in to ensure a simple reproduction of organic matter in the soil) is estimated at about

\footnotetext{
${ }^{4}$ The Polish FADN data made it possible to determine the consumption of purchased animal manure only in value terms (PLN/farm). In order to estimate the amount of consumed purchased animal manure, the findings of the Zachodniopomorski Agricultural Advisory Centre in Barzkowice on the price of 1 tonne of manure in 2015 were used (www.zodr.pl).

${ }^{5}$ The permanent coefficient applied at the Institute of Soil Science and Plant Cultivation National Research Institute and amounting to 0.7 tonne/ha was used to convert the area of green manure on the farm into the weight of organic matter introduced into soil.
}

${ }^{6}$ Molecular mass is commonly expressed in atomic mass units where 1 unit $=1.66 * 10-24 \mathrm{~g}$. 
13.5 million tonnes (Madej, 2016). This surplus may be allocated for energy needs. In order to determine the energy value of the surplus of straw, Table 1 provides its calorific value and other characteristics compared to wood and hard coal.

Table 1

Comparison of the composition and calorific value of biomass and hard coal extracted in Poland

\begin{tabular}{|c|c|c|c|c|c|c|c|c|}
\hline \multirow{2}{*}{$\begin{array}{l}\text { Name } \\
\text { of fuel }\end{array}$} & \multicolumn{4}{|c|}{ Content of element ${ }^{\mathrm{a}}$ ( $\%$ of weight) } & \multirow{2}{*}{$\begin{array}{l}\text { Moisture } \\
\text { content } \\
(\%)\end{array}$} & \multirow{2}{*}{$\begin{array}{l}\text { Calorific } \\
\text { value } \\
(\mathrm{MJ} / \mathrm{kg})\end{array}$} & \multirow{2}{*}{$\begin{array}{c}\text { Volatile } \\
\text { matter } \\
(\%)\end{array}$} & \multirow{2}{*}{$\begin{array}{l}\text { Ash } \\
\text { content } \\
(\%)\end{array}$} \\
\hline & $\mathrm{C}_{\text {sr }}$ & $\mathrm{N}$ & S & $\mathrm{CL}$ & & & & \\
\hline Straw & 48 & $0.28-0.8$ & $0.05-0.16$ & $0.15-0.8$ & $12-20$ & $12-17.3$ & $70-75$ & $4-6$ \\
\hline Wood & 52.5 & $0.08-0.3$ & $0.02-0.12$ & $<0.11$ & $30-55$ & $6-13$ & $70-87$ & $0.2-0.4$ \\
\hline $\begin{array}{l}\text { Hard } \\
\text { coal }\end{array}$ & 82 & $0.6-2.0$ & $0.53-2.5$ & $\begin{array}{l}\text { avg. 0.12 } \\
\text { (max. 0.2) }\end{array}$ & $6-13$ & $18.3-25$ & 35 & $20-27$ \\
\hline
\end{tabular}

a in working state, in which the fuel is used - burned.

Source: Janka (2012).

The calorific value of straw amounting, on average, to $14.6 \mathrm{MJ} / \mathrm{kg}$, is by about $53 \%$ higher than the calorific value of wood, but by $32 \%$ lower than the calorific value of hard coal, which is, on average, $21.6 \mathrm{MJ} / \mathrm{kg}$. This means that one tonne of hard coal in terms of its calorific value can be replaced by 1.48 tonnes of straw. The allocation of 13.5 million tonnes of straw for energy purposes can replace 9.1 million tonnes of hard coal, which accounts for $12.6 \%$ of the total consumption of hard coal for energy purposes in 2015 (GUS, 2016a). At the same time, the combustion of straw emits the double amount of volatile substances to the atmosphere than the combustion of hard coal, which adversely affects human health. Straw has also higher content of chlorine which during the combustion process causes corrosion of boilers (Janka, 2012).

Straw contains macronutrients and trace elements, and Table 2 provides the contents of basic macronutrients in various types of straw. By assuming the average dry matter content in straw at the level of $85 \%$, the content of macronutrients in one tone of burnt straw was calculated based on the data from Table 2, and these values are, respectively: nitrogen $(\mathrm{N})-5.88 \mathrm{~kg}$, phosphorus $\left(\mathrm{P}_{2} \mathrm{O}_{5}\right)-2.36 \mathrm{~kg}$; potassium $\left(\mathrm{K}_{2} \mathrm{O}\right)-11.65 \mathrm{~kg}$; calcium $(\mathrm{CaO})-4.83 \mathrm{~kg}$, and magnesium $(\mathrm{MgO})-0.56 \mathrm{~kg}$. With the average yield of straw amounting to 4 tonnes per ha, when we burn it for energy purposes, we lose irretrievably from 1 ha of cereals and rapeseed: $23.52 \mathrm{~kg}$ of N, $9.44 \mathrm{~kg}$ of $\mathrm{P}_{2} \mathrm{O}_{5}, 46.4 \mathrm{~kg}$ of $\mathrm{K}_{2} \mathrm{O}, 19.32 \mathrm{~kg}$ of $\mathrm{CaO}$ and $2.24 \mathrm{~kg}$ of $\mathrm{MgO}$. On a national scale, assuming that the surplus of straw amounting to 13.5 million tonnes is fully used for energy purposes (combustion), losses will be: $79380^{7}$ tonnes of $\mathrm{N}$, 31860 tonnes of $\mathrm{P}_{2} \mathrm{O}_{5}, 157275$ tonnes of $\mathrm{K}_{2} \mathrm{O}$. The total NPK losses (in pure component) will be 268515 tonnes, which accounts for $15 \%$ of the total NPK consump-

\footnotetext{
${ }^{7}$ Using the coefficient of nitrous oxide emissions from $1 \mathrm{~kg}$ of $\mathrm{N}(0.01)$, as determined by the Intergovernmental Panel on Climate Change, it can be estimated that this loss is equal to emissions of 236.6 tonnes of nitrous oxide $\left(\mathrm{N}_{2} \mathrm{O}\right)$ expressed in $\mathrm{CO}_{2}$ equivalent.
} 
tion in 2014/2015, which was 1729300 tonnes (GUS, 2016a). In addition to NPK, straw used for energy purposes contains 65205 tonnes of $\mathrm{CaO}$, which accounts for $11.5 \%$ of used agricultural lime in 2014/2015 and 7560 tonnes of MgO. Regardless of the above-mentioned macronutrients, straw also contains trace elements such as boron, copper, manganese, molybdenum and zinc, which play an important role in the growth and development of plants.

Table 2

Content of basic macronutrients in straw

\begin{tabular}{lccccccc}
\hline \multirow{7}{*}{ Components } & \multicolumn{7}{c}{ Crop species } \\
\cline { 2 - 8 } & $\begin{array}{c}\text { Winter } \\
\text { wheat }\end{array}$ & $\begin{array}{c}\text { Winter } \\
\text { triticale }\end{array}$ & Rye & Oat & $\begin{array}{c}\text { Spring } \\
\text { barley }\end{array}$ & Rapeseed & Maize \\
\hline $\mathrm{N}$ & 0.64 & 0.61 & 0.58 & 0.73 & 0.75 & 0.72 & 1.19 \\
$\mathrm{P}_{2} \mathrm{O}_{5}$ & 0.23 & 0.25 & 0.25 & 0.34 & 0.25 & 0.30 & 0.48 \\
$\mathrm{~K}_{2} \mathrm{O}$ & 1.26 & 1.28 & 1.20 & 1.29 & 1.61 & 2.12 & 1.25 \\
$\mathrm{CaO}$ & 0.38 & 0.35 & 0.32 & 0.44 & 0.63 & 2.18 & 0.48 \\
$\mathrm{MgO}$ & 0.15 & 0.13 & 0.13 & 0.18 & 0.20 & 0.21 & 0.48 \\
\hline
\end{tabular}

Source: Kuś and Kopiński (2012).

Macronutrients losses can also be expressed in value terms, assuming the unit ${ }^{8}$ value of these macronutrients in mineral fertilisers purchased by farmers. These losses are:

\begin{tabular}{|c|c|c|}
\hline vitrogen & 79380 tonnes x PLN 3600 & $=$ PLN 285768000 \\
\hline Phosphorus & 31860 tonnes x PLN 4060 per tonne & $=$ PLN 129351600 \\
\hline Potassium & 157275 tonnes x PLN 2570 per tonne & PLN 404196750 \\
\hline Calcium & 65205 tonnes x PLN 3220 per tonne & $=$ PLN 209960100 \\
\hline Magnesium & 7560 tonnes x PLN 4160 per tonne & PLN 31449600 \\
\hline
\end{tabular}

Total

PLN 1060726050

\section{Role of organic matter in soil}

The soil fertility, which is understood as the capacity to "yield", is determined by the group of its physical, chemical and biological properties. These properties depend on the content of humus which is the main component $(70-80 \%)$ of soil organic matter (Kuś and Kopiński, 2012) it determines:

- soil ability to retain and release minerals into the soil water (soil absorption capacity); the colloidal structure of this matter enables the absorption of nutrients of plants 4-12 times more than mineral fractions of soil, in addition they are readily available to plants;

\footnotetext{
${ }^{8}$ The unit cost of $1 \mathrm{~kg}$ of pure component has been calculated based on the prices of fertilisers of August 2017 (Zalewski, 2017).
} 
- soil ability to retain and collect water, as humus retains 3-5 times more water available to plants in relation to its weight;

- lumpy structure of soil facilitating mechanical tillage and decreasing its susceptibility to erosion, as it provides a binder for the solid phase of soil;

- dark colour and thermal properties of soil (heating rate in spring);

- ability to absorb, on its surface, heavy metals and toxic substances (e.g. pesticides) up to the moment of their decomposition by soil microorganisms;

- soil biological activity, as organic matter is a source of carbon and other nutrients, particularly, nitrogen, phosphorus and trace elements;

- buffer capacity of soil.

As already mentioned, the share of soils with the low organic matter content (less than 2\%) in Poland is very high and is about 90\%. However, when farming in accordance with the principles of good agricultural practice, we can increase, to some extent, the organic matter content in soil, thereby improving not only its yielding capacity, but also contributing to sequestration of additional $\mathrm{CO}_{2}$ from the atmosphere in it. It should be stressed that on the farm an important way to increase the organic matter content in soil is ploughing in of straw ${ }^{9}$.

\section{Ploughing in of straw as a practice to sequestrate $\mathrm{CO}_{2}$ in the LULUCF area ${ }^{10}$}

According to the draft Regulation of the European Parliament and of the Council of 16 October 2017, by 2030 Poland should reduce greenhouse gas emissions within the Effort Sharing Regulation (ESR) ${ }^{11}$ area by $7 \%$ when compared to the level of 2005 (Council of the European Union, 2017). Bearing in mind that in the Member States reductions of greenhouse gas emissions within the ESR area should apply to all sectors, Poland will have to make an effort to reduce greenhouse gas emissions also in the agricultural sector, whose annual greenhouse gas emissions are approximately $17 \%$ (in $2015-16.8 \%$ ) of the total emissions of these gases in the ESR area ${ }^{12}$ (Ministerstwo Środowiska, 2016) (Fig. 1).

\footnotetext{
${ }^{9}$ It is worth remembering that the reduction in the organic matter content as a result of the pursued agricultural activity, particularly on light soils, quickly results in a noticeable reduction in yields. In Poland, this reduction may amount up to $20 \%$ (Faber and Jarosz, 2016). This situation is all the more alarming, as, according to the findings of the Economics of Farm Holdings Department at the Institute of Agricultural and Food Economics - National Research Institute, farming opportunities on these soils without losses in organic matter resources are limited (Balance of substances..., 2018).

${ }^{10}$ The Land Use, Land Use Change and Forestry area (LULUCF) - according to the methodology of the Intergovernmental Panel on Climate Change (IPCC), in the LULUCF area the balance of $\mathrm{CO}_{2}$ sequestration from the atmosphere is estimated in total from the sectors of forestry land, afforested and deforested land, permanent grassland as well as arable land, wetland and inhabited areas.

${ }^{11}$ The ESR area includes greenhouse gas emissions from the following sectors: transport, waste, construction (municipal and services), extraction, processing and transport of fuels, from industrial processes not included in the ETS area and from agriculture (Ministerstwo Środowiska, 2016).

${ }^{12}$ The need for a more ambitious involvement of the agricultural sector in reducing greenhouse gas emissions has also been included in the Communication from the Commission to the European Parliament, the Council, the European Economic and Social Committee and the Committee of the Regions: the Future of Food and Farming.
} 


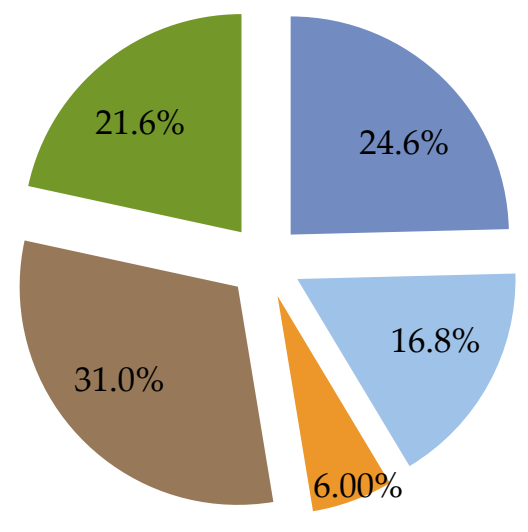

Transport $\square$ Agriculture $\square$ Waste $\square$ Construction $\quad$ Other

Fig. 1. Structure of greenhouse gas emissions in the ESR area in Poland in 2015.

Source: own study based on KOBiZE (2017).

It should be noted that in the agriculture sector many currently applicable practices to reduce greenhouse gas emissions can increase the production costs while having no positive impact on its value (IZ-PIB, 2015). Given the above, we should therefore recognise the correctness of the findings by the European Parliament and of the Council of 2016 and 2017 concerning the possibility for the Member States to include a certain contribution of the LULUCF area in reducing greenhouse gas emissions from the ESR area. by 2030 (European Parliament, 2016; Council of the European Union, 2017). According to these findings, the opportunities for $\mathrm{CO}_{2}$ sequestration from the atmosphere in the LULUCF area which can be used, to a certain extent, to decrease the effort to reduce greenhouse gas emissions from the ESR area by 2030 should be sought both in the forest and permanent grassland sectors and in the arable land sector. This is an advantage to this approach, as there are also the opportunities for $\mathrm{CO}_{2}$ sequestration in the arable land sector. In this context, the positive role of ploughing in of straw in soil should be emphasised first of all.

As stated in the previous subchapter, the surplus of straw in Polish agriculture, according to the available estimates, is about 13.5 million tonnes per year. Assuming that 1 tonne of straw with dry matter content of $85 \%$ produces $180 \mathrm{~kg}$ of organic matter in which the organic carbon content is $58 \%$, the potential volume of sequestrated $\mathrm{CO}_{2}$ may be calculated. It will be $383.1 \mathrm{~kg}$ (as: $180 \mathrm{~kg} \times 0.58 \times 3.67=383.1 \mathrm{~kg}$ ). However, considering that, on average, only about $20 \%$ of sequestrated $\mathrm{CO}_{2}$ is subject to permanent sequestration in soil (Faber et al., 2012; Jarosz, 2016), it should be stressed that on a national scale total $\mathrm{CO}_{2}$ sequestration resulting from ploughing in of the surplus of straw would be 1034.6 thousand tonnes and would account for about $3.5 \%$ of total $\mathrm{CO}_{2}$ sequestration in the LULUCF area (KOBiZE, 2017). 


\section{Economic situation of farms with the non-negative $\mathrm{CO}_{2}$ sequestration balance against the background of other farms}

Bearing in mind that the relationships between the amount of organic matter derived from 1 tonne of ploughing in of straw of arable crops and its organic carbon content are known, it is worth indicating the direction and strength of the impact of the $\mathrm{CO}_{2}$ sequestration balance on the economic results and development opportunities of the farms specialising in the cultivation of cereals, oilseeds and protein crops ${ }^{13}$. Analysis decided to describe the farms specialising in the cultivation of cereals, oilseeds and protein crops, as - according to the authors - the specialisation in the cultivation of these crops, despite many advantages, entails also some risks. An important risk in this type of farms is the absence or scarcity of animal manure, whose primary function is to improve the balance of soil organic matter. These farms are, therefore, threatened by a reduction in the yielding potential of land, as well as the additional $\mathrm{CO}_{2}$ emissions from organic matter subject to mineralisation in the soil.

However, in the case of the farms specialising in the cultivation of cereals, oilseeds and protein crops, there are other options to improve the balance of soil organic matter. The most important is ploughing in of straw of properly prepared straw, which leads to an increase in the share of soil organic matter and, consequently, also to the improved $\mathrm{CO}_{2}$ sequestration balance ${ }^{14}$. But it is important whether for farms specialising in the cultivation of cereals, oilseeds and protein crops, ploughing in of crops straw is also positive for their economic effects and development.

In comparative analysis of the farms with the non-negative balance I and II and of other farms, their average $\mathrm{CO}_{2}$ sequestration balance was taken into account in the first place. Their production potential, productivity of the basic production factors, income per 1 ha of UAA and per 1 FWU and the development opportunities were further established.

In the farms with the non-negative balance I and II, the average $\mathrm{CO}_{2}$ sequestration balance was, respectively, 602.2 and $270.8 \mathrm{~kg} / \mathrm{year}$, while for other farms it was negative and amounted to $-295.8 \mathrm{~kg} /$ year (Fig. 2).

\footnotetext{
${ }_{13}$ Type 15 (according to the Polish FADN).

${ }^{14}$ However, it is worth remembering that the decomposition rate of ploughing in of straw into soil depends on several conditions. Among them, it is worth mentioning its proper shredding, application of nitrogen ( $\sim 6-8$ $\mathrm{kg} /$ tonne of straw) and the best possible mixing with soil.
} 


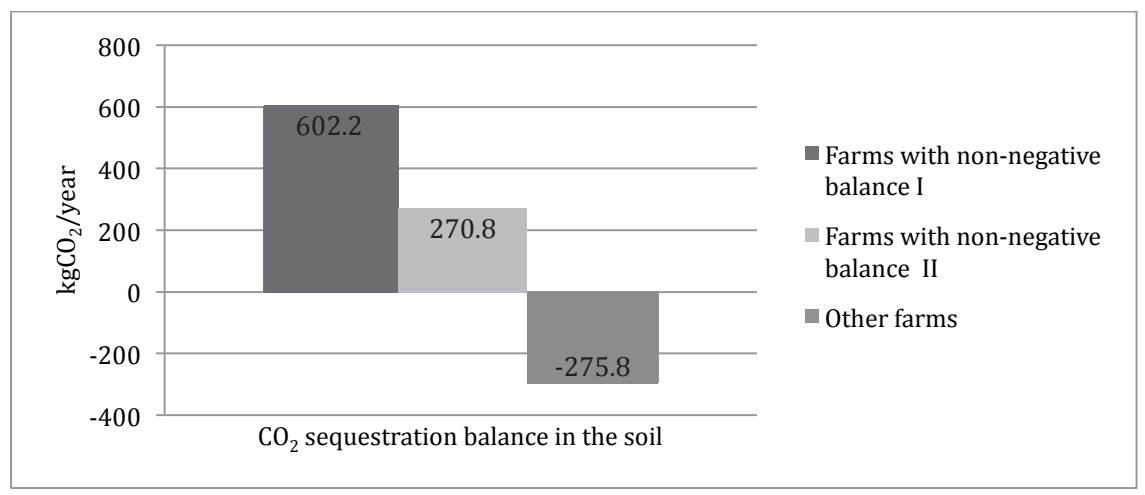

Fig. 2. $\mathrm{CO}_{2}$ sequestration balance from the atmosphere in the analysed farms specialising in the cultivation of cereals, oilseeds and protein crops in 2015.

Source: own study based on the Polish FADN data for 2015.

As it results from the figures in Table 3, the farms with the non-negative balance I and II against the background of other farms had a larger area of UAA by $17.7 \%$ and $21.9 \%$, respectively. This was also the case of labour inputs per farm. In the farms with the non-negative balance I and II, labour inputs per farm were at the level higher by $6.7 \%$ than on other farms. However, per 1 ha of UAA, they were lower by, respectively, $9.4 \%$ and $12.5 \%$. An important reason for these differences was the fact that the farms with the non-negative balance I and II were better equipped with machinery, agricultural equipment and buildings, as reported by their average capital value higher by, respectively, $47.6 \%$ and $29.5 \%$.

Table 3

Production potential of the analysed farms specialising in the cultivation of cereals, oilseeds and protein crops based on the Polish FADN data in 2015

\begin{tabular}{lcccc}
\hline \multirow{2}{*}{ Specification } & Unit of & \multicolumn{3}{c}{ Farms: } \\
\cline { 3 - 5 } & measurement & $\begin{array}{c}\text { with the non-negative } \\
\text { balance I }\end{array}$ & $\begin{array}{c}\text { with the non-negative } \\
\text { balance II }\end{array}$ & other \\
\hline UAA & ha & 65.1 & 67.4 & 55.3 \\
$\begin{array}{l}\text { Total labour inputs } \\
\text { per farm }\end{array}$ & AWU & 1.6 & 1.6 & 1.5 \\
$\begin{array}{l}\text { Total labour inputs } \\
\text { per 1 ha of UAA }\end{array}$ & hour & 52.1 & 50.3 & 57.5 \\
Average capital value & PLN thousand & 797.8 & 699.7 & 540.5 \\
\hline
\end{tabular}

Source: own study based on the Polish FADN data for 2015.

The important information about the farms with the non-negative balance I and II and about other farms are also provided by the productivity of their basic production factors. It has been noted that in the farms with the non-negative balance I and II, when compared to other farms, the land productivity expressed as the value of total 
production per 1 ha of UAA was higher by, respectively, $70.4 \%$ and $29.6 \%$. The same direction of differences was in the case of the capital productivity and labour productivity. The farms with the non-negative balance I and II had the capital productivity higher by, respectively, 9.8 and 5.7 percentage points (p.p.) and the labour productivity by, respectively, $87.3 \%$ and $46.2 \%$ (Table 4 ).

The above-mentioned differences in the productivity of basic production factors among the farms with the non-negative balance I and II and other farms were reflected in income per 1 ha of UAA and per $1 \mathrm{FWU}$. In the first case, for the farms with the non-negative balance I and II, this income was higher by, respectively, $111.1 \%$ and $44.4 \%$ and, for the other, by, respectively $133.5 \%$ and $65.3 \%$. However, it is necessary to add that all three analysed groups of the farms provided the payment for labour of the owner and members of his family at the parity level corresponding to the average annual net salary in the national economy ${ }^{15}$.

The better economic situation of both groups of the farms with the non-negative balance allowed their managers to invest more in fixed assets. For the farms with the non-negative balance I and II, the net investment rate was, in fact, $31.4 \%$ and $59.1 \%$, respectively, while for other farms it was $15.2 \%$ (Table 4 ).

Table 4

Productivity of production factors, income and development opportunities

of the analysed farms specialising in the cultivation of cereals, oilseeds and protein crops based on the Polish FADN data in 2015

\begin{tabular}{|c|c|c|c|c|}
\hline \multirow[b]{2}{*}{ Specification } & \multirow{2}{*}{$\begin{array}{c}\text { Unit of } \\
\text { measurement }\end{array}$} & \multicolumn{3}{|c|}{ Farms: } \\
\hline & & $\begin{array}{c}\text { with the non-negative } \\
\text { balance I }\end{array}$ & $\begin{array}{c}\text { with the non-negative } \\
\text { balance II }\end{array}$ & other \\
\hline Land productivity & $\begin{array}{l}\text { PLN } \\
\text { thousand / ha }\end{array}$ & 4.6 & 3.5 & 2.7 \\
\hline Capital productivity & $\%$ & 37.4 & 33.3 & 27.6 \\
\hline Labour productivity & $\begin{array}{c}\text { PLN } \\
\text { thousand / AWU }\end{array}$ & 186.6 & 145.6 & 99.6 \\
\hline $\begin{array}{l}\text { Income per } 1 \text { ha } \\
\text { of UAA }\end{array}$ & $\begin{array}{l}\text { PLN } \\
\text { thousand / ha }\end{array}$ & 1.9 & 1.3 & 0.9 \\
\hline Income per $1 \mathrm{FWU}$ & $\begin{array}{c}\text { PLN } \\
\text { thousand / AWU }\end{array}$ & 78.0 & 55.2 & 33.4 \\
\hline Net investment rate & $\%$ & 31.4 & 59.1 & 15.2 \\
\hline
\end{tabular}

Source: own study based on the Polish FADN data for 2015.

\footnotetext{
${ }^{15}$ In 2015, the average net salary in the national economy was PLN 31.2 thousand (Żekało, Abramczuk, Czułowska and Jabłoński, 2016).
} 


\section{Conclusions}

It is estimated that in Polish agriculture there is the surplus of straw of about 13.5 million tonnes. It may be allocated for energy purposes or as a source of additional soil organic matter. Analysis showed that:

- The allocation of the surplus of straw for energy purposes in Polish agriculture may reduce the consumption of hard coal by $12.6 \%$, although it will result in greater emissions into the atmosphere of volatile substances which adversely affect human health. What is more, the weaknesses of such a solution are also significant losses of macronutrients contained in straw. It is estimated that on a national scale, the allocation of the surplus of straw for energy purposes will result in total losses of nitrogen, phosphorus and potassium amounting to about 268515 tonnes, which accounts for $15 \%$ of the total consumption of NPK mineral fertilisers in 2014/2015. On the other hand, in the case of calcium, these losses amount to 65205 tonnes, corresponding to $11.5 \%$ of used agricultural lime in 2014/2015. In the case of magnesium, losses will be 7560 tonnes. In value terms, total losses of macronutrients will, therefore, be about PLN 1.06 billion. Important are also losses of trace elements contained in straw, such as boron, copper, manganese, molybdenum and zinc, which play an important role in the growth and development of plants.

- The allocation of the surplus of straw in Polish agriculture for ploughing in of straw is able to improve the yielding potential of Polish soils, whose average quality is the lowest in the EU. It should be remembered that in Poland more than 3.7 million ha of the potential agricultural area ${ }^{16}$ have the average agricultural production area valorisation (APAV) of less than 52 out of 120 points to be scored ${ }^{17}$. This means that there is a significant area of potential UAA in Poland with a particularly unfavourable physical structure of soils and often with the trace content of organic matter. Moreover, ploughing in of the surplus of straw will allow to accumulate additional 1034.6 thousand tonnes of $\mathrm{CO}_{2}$ per year. Thus, ploughing in of straw would positively affect the contribution of the LULUCF area, including the arable land sector, to decreasing the effort of reducing greenhouse gas emissions from the ESR area by 2030. In addition, the studies have shown that the farms ploughing in of straw, in the amount that gives them the non-negative $\mathrm{CO}_{2}$ sequestration balance when compared to other farms, obtain the higher productivity levels of basic production factors and are, consequently, in the better economic situation and have more development opportunities.

- In connection with the fact that in Poland there are areas with the particularly unfavourable quality of soils that require urgent action so as to at least sustain their production functions and taking into account the need for the LULUCF sector's contribution to decreasing the effort to reduce greenhouse gas emissions in the ESR sector by 2030, it should be stressed that the surplus of straw found in Polish agriculture should serve as an additional source of soil organic matter.

\footnotetext{
${ }^{16}$ According to the cadastral and geodetic area (peg).

${ }^{17}$ Data from the Institute of Soil Science and Plant Cultivation - National Research Institute.
} 


\section{References}

Bilans substancji organicznej na glebach Polski (2018). Maszynopis. Warszawa: Zakład Ekonomiki Gospodarstw Rolnych, IERiGŻ-PIB.

Communication from the Commission to the European Parliament, the Council, the European Economic and Social Committee and the Committee of the Regions: the Future of Food and Farming. European Commission, 29.11.2017.

Council of the European Union (2017). Proposal for a Regulation of the European Parliament and of the Council of 16 October 2017 on the inclusion of greenhouse gas emissions and removals from land use, land use change and forestry into the 2030 climate and energy framework and amending Regulation No. 525/2013 of the European Parliament and the Council on a mechanism for monitoring and reporting greenhouse gas emissions and other information relevant to climate change - general approach.

European Parliament (2016). Proposal for a Regulation of the European Parliament and of the Council on the inclusion of greenhouse gas emissions and removals from land use, land use change and forestry into the 2030 climate and energy framework and amending Regulation No. 525/2013 of the European Parliament and the Council on a mechanism for monitoring and reporting greenhouse gas emissions and other information relevant to climate change.

Faber, A., Borek, R., Borzęcka-Walker, M., Jarosz, Z., Kozyra, J., Pudełko, R., Syp, A., Zaliwski, A. (2012). Bilans węgla i emisji gazów cieplarnianych $\left(\mathrm{CO}_{2}, \mathrm{CH}_{4}\right.$ oraz $\left.\mathrm{N}_{2} \mathrm{O}\right)$ w polskim rolnictwie. J.S. Zegar (ed.). Z badań nad rolnictwem społecznie zrównoważonym (15). Program Wieloletni 2011-2014, no. 50, pp. 9-37. Warszawa: IERiGŻ-PIB.

Faber, A., Jarosz, Z. (2016). Jak zmniejszyć emisję gazów cieplarnianych w uprawie surowców przeznaczonych na cele produkcji biopaliw płynnych. Puławy: IUNG-PIB.

Fotyma, M., Mercik, S. (1995). Chemia rolna. Warszawa: PWN.

Gonet, S.S. (2007). Materia organiczna w Tematycznej Strategii Ochrony Gleb Unii Europejskiej. Roczniki gleboznawcze, no. 58(3/4), pp. 15-26.

GUS (2016a). Rocznik Statystyczny Rolnictwa. Warszawa.

GUS (2016b). Zużycie paliw i nośników energii w 2015 r. Warszawa.

Harasim, A. (2006). Przewodnik ekonomiczno-rolniczy w zarysie. Puławy: IUNG-PIB.

IZ-PIB (2015). Potencjat redukcji emisji gazów cieplarnianych w polskim rolnictwie z uwzględnieniem efektów Wspólnej Polityki Rolnej. Ekspertyza wykonana dla MRiRW. Warszawa: Uniwersytet Przyrodniczy w Lublinie, ITP, SGGW, IERiGŻ-PIB.

Janka, R.M. (2012). Ocena ekologiczno-energetyczna wybranych technologii spalania słomy. Proceedings of ECOpole, z. 6, no. 1, pp. 325-330.

Jarosz, Z. (2016). Potencjał techniczny słomy w Polsce i efekty środowiskowe jej alternatywnego wykorzystania. Roczniki Naukowe SERiA, t. XVIII, z. 1, pp. 84-89.

KOBiZE (2017). Poland's National Inventory Report 2017. IOŚ-PIB.

Kuś, J., Kopiński, J. (2012). Gospodarowanie glebową substancją organiczną we współczesnym rolnictwie. Zagadnienia Doradztwa Rolniczego, no. 2(68), pp. 5-27.

Madej, A. (2016). Bilans słomy w Polsce w latach 2010-2014 oraz prognoza do 2030 roku. Roczniki Naukowe SERiA, t. XVIII, z. 1, pp. 163-168.

Ministerstwo Środowiska (2016). Sytuacja emisyjna $w$ sektorach non-ETS w perspektywie roku 2030 w odniesieniu do potencjalnego celu redukcyjnego dla Polski. Warszawa.

Zalewski, A. (2017). Rynek środków produkcji dla rolnictwa. Rynek Rolny, no. 9(319), pp. 77-80.

Żekało, M., Abramczuk, Ł., Czułowska, M., Jabłoński, K. (2016). Produkcja, koszty i dochody $z$ wybranych produktów rolniczych w latach 2014-2015. Warszawa: IERiGŻ-PIB.

www.zodr.pl. 


\title{
SŁOMA JAKO ALTERNATYWNE ŹRÓDŁO ENERGII LUB MATERII ORGANICZNEJ W GLEBIE
}

\begin{abstract}
Abstrakt
Podstawowym celem opracowania jest próba oceny skutków przeznaczania nadwyżki stomy występujacej w polskim rolnictwie na cele energetyczne lub jako źródto dodatkowej materii organicznej w glebie. W zwiazku z tym omówiono zagadnienie dotyczace znaczenia słomy jako alternatywnego źródła energii oraz zwrócono uwage na role materii organicznej $w$ poprawie potencjatu produkcyjnego gleb i sekwestracji dwutlenku węgla $\left(\mathrm{CO}_{2}\right)$. Co więcej, ocenie poddano ekonomiczne skutki i możliwości rozwoju gospodarstw rolnych posiadajacych nieujemne saldo sekwestracji $\mathrm{CO}_{2}$ na tle pozostatych gospodarstw. W opracowaniu wykorzystano dane literaturowe oraz dane z 2069 gospodarstw rolnych specjalizujących się $w$ uprawie zbóż, roślin oleistych i wysokobiałkowych, które prowadzity rachunkowość dla Polskiego FADN w 2015 roku.
\end{abstract}

Słowa kluczowe: słoma, energia, materia organiczna, sekwestracja $\mathrm{CO}_{2}$, gospodarstwo rolne, alternatywa.

Accepted for print: 15.06.2018.

Unless stated otherwise all the materials on the website are available under the Creative Commons Attribution 4.0 International license.

Some rights reserved to the Institute of Agricultural and Food Economics - National Research Institute.

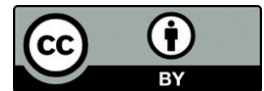

